\title{
Building Bridges and Borders with Deficit Thinking
}

\author{
Jill Koyama' \\ Suzanne Desjardin"
}

'University of Arizona (UA), Tucson/AZ - United States of America "Pima Community College (PCC), Tucson/AZ - United States of America

\begin{abstract}
Building Bridges and Borders with Deficit Thinking. In this paper, we look at a high school to college transition program intended to prepare Latinx youth living in Arizona, a southwestern US border state, to negotiate, if not cross, borders, including those associated with accessing college. Purposefully, we problematize the at-risk discourses that reify the nature of these border landscapes within neoliberal framings aimed at explaining educational patterns of Latinxs and that infuse the college bridge program we examine. We demonstrate that while the program provides social and cultural capital, as well as additional temporary academic supports that high school students need to navigate college-going processes, it is also embedded with deficit perspectives that frame Latinxs as at-risk because of their culture, ethnicity, and language, or conversely, disregard their heritage entirely. Finally, we offer recommendations for future research of bridge and transition programs. We argue for turning examinations upside down to resituate and reconsider, and potentially dismantle, the enactments of at-risk deficit thinking, which still undergird many programs aimed at mediating borders experienced by Latinxs in the US.
\end{abstract}

Keywords: Latinx. US-MX Border. College Transition. AVID.

RESUMO - Construindo Pontes e Fronteiras com o Pensamento de Déficit. Neste artigo, olhamos para um programa de transição do ensino médio para a faculdade voltado a preparar jovens latinxs que vivem no Arizona, um estado fronteiriço no sudoeste dos EUA, para que contornem, quiçá atravessem, fronteiras, incluídas aquelas associadas ao acesso à faculdade. Intencionalmente, problematizamos os discursos de situação de risco que reificam a natureza dessas paisagens fronteiriças dentro de enquadramentos neoliberais que visam explicar padrões educacionais de latinxs e que inspiram o programa de transição para a faculdade que examinamos. Demonstramos que, embora o programa forneça capital social e cultural, bem como suporte acadêmico temporário adicional necessário para que alunos do ensino médio atravessem os processos de ingresso na faculdade, ele também está envolto em perspectivas de déficit que enquadram xs latinxs como situação de risco devido a sua cultura, etnicidade e idioma, ou, inversamente, desconsideram inteiramente sua herança. Por fim, propomos recomendações para futuras pesquisas sobre programas preparatórios e de transição. Defendemos a inversão das análises para restituir e reconsiderar, e potencialmente desmantelar, as representações do pensamento deficitário de situação de risco, que ainda sustentam muitos programas destinados a mediar fronteiras vivenciadas por latinxs.

Palavras-chave: Latinxs. Fronteira EUA-México. Transição para a faculdade. $A V I D$.

Educação \& Realidade, Porto Alegre, v. 44, n. 2, e86415, 2019.

http://dx.doi.org/10.1590/2175-623686415 
Building Bridges and Borders with Deficit Thinking

\title{
Introduction
}

Latinx high school students living in Arizona, a southwestern state in the United States (US) face multiple borders ${ }^{1}$. Their daily lives are impacted by their location in what Rajaram and Grundy-Warr (2007) refer to as borderscapes, landscapes in which borders exist and gain meaning. These Latinx youth live on the US side of the officially regulated geographic, political, and economic US-Mexican border, but often have deep ties to, and family living in, Mexico (MX). They are impacted by Arizona's anti-Mexican and anti-immigrant legislation, such including a law that requires police to ascertain the immigration status of anyone detained, and some are personally affected by deportment of family and friends. In school, they are denied ethnic or Mexican American Studies by state law and many are subjected to English for the Children, legislation that mandates that students who do not speak English as their mother tongue be taught in English immersion (Wright, 2005). These students, who we refer to as emergent bilinguals (García, 2011), are categorized, sorted, and segregated on one side of a linguistic border for four-hour blocks of English instruction that restricts their enrollment in science and mathematics courses required for college entrance ${ }^{2}$. Complicating the segregation in Structured English Immersion (SEI) classes for much of the school day, Latinxs are more likely than any other ethnic or racial group of students to be segregated in schools that are lacking in resources and qualified teachers (Gándara; Hopkins, 2010).

Further, throughout the US school system, many Latinxs do not earn a high school degree. Of the graduates, just over half enter college, and most of them enroll in community college; however, less than half of Latinx students attending community college graduate. Gonzalez (2013, p. 2-3) summarizes:

\begin{abstract}
If we follow 100 elementary school students throughout their educational careers [...] of 100 Latino students who begin [...] only 46 will graduate from high school. Of those 46 , only 26 will enroll in college. Of the 26,17 will attend community college and 9 will attend 4 -year colleges. Of the 17 community college students only 8 will graduate with a Bachelor's degree.
\end{abstract}

Similarly, Núñez and Elizondo (2013) document that the transfer rate from community colleges to universities for Latinxs, continues to trail far behind any other racial group, thus ultimately impacting overall bachelor degree attainment by Latinxs. Their data show that Latinx students continue to lag behind Whites in postsecondary pursuits.

In this paper, we look at a high school to college transition program intended to prepare southern Arizona Latinx youth to negotiate, if not cross, borders, including those associated with accessing college. First, we consider three interrelated borders that can impact the education of Latinxs in southern Arizona. We interrogate at the border between Arizona and Mexico, the K-12 academic achievement margins between Latinxs and their White counterparts, and the persistent lacu- 
nae between Latinxs who enter high school and those who attend college. Purposefully, we problematize the at-risk discourses that reify the nature of these border landscapes within neoliberal framings aimed at explaining educational patterns of Latinxs and that infuse the bridge program we examine. At-risk notions, when applied to Latinx students locate blame on the individual students without providing adequate culpability to the institutional and societal processes and phenomena that impact the students' academic experiences. Often, such thinking places culpability on the students' linguistic, ethnic, racial, and socioeconomic background, rather than on the institutional practices of schooling.

Applying our thinking to controversies revealed in the qualitative case study of the bridge program, conducted by the second author, we demonstrate that while the program provides social and cultural capital, as well as additional temporary academic supports that high school students need to navigate college-going processes, it is also embedded with deficit perspectives that frame Latinxs as at-risk because of their culture, ethnicity, and language, or conversely, disregard their heritage. Finally, we offer recommendations for future research of bridge and transition programs. We argue for turning examinations upside down to resituate and reconsider, and potentially dismantle, the enactments of at-risk deficit thinking, which still undergird many programs aimed at mediating borders experienced by Latinxs.

\section{Borders}

Although some borders, such as ones between nation-states are physical, and all too real for those unable to cross them, borders are also socially constructed (and deconstructed). Most are emergent, in the process of becoming rather than being, and the landscapes on either side of borders are "[...] repositories of contesting interpretations of meaning" (Rajaram; Grundy-Warr, 2007, p. 25). In aiming to understand the education of Latinxs in Southern Arizona, we explore the ways in which borders not only construct rudimentary lines of demarcation, but also further categorize people and frame their educational trajectories.

\section{The US-Mexico Border}

The US-Mexico border remains an important site of exchange and exclusion. As a political and economic border, it continues to wield influence, creating uneven movements of people, goods, and currency. The politics of difference, including the economic uncertainties and historical inequities become amplified at borders between nationstates, such as the US and Mexico, with disparate global influence and standing. The border between Mexico and the US has long been a site of conflict, a zone of resistance, and a space of multiple enactments of inclusion and exclusion, belonging and not belonging. Although it is greater than fifty miles where the Latinx youth in our study attend 
school, the Mexico-US border maintains a symbolic and social border in their lives. It is a site where power is exerted, and across which certain power moves unevenly.

Economic conditions along the border are imbalanced compared to other areas of the US. Velasco Ortiz and Contreras $(2014$, p. 38) argue, in fact, that "[...] there is no other border in the world with greater inequity in terms of power, economic development and social conditions". $18 \%$ of Arizonans live below the poverty and Southern Arizonan families disproportionally live in poverty. Sixty-six percent of Latinx youth in Arizona qualify for and receive free or reduced lunch (Milem; Salazar; Bryan, 2016). As Lusk, Staudt, and Moya (2012, p. 25) state: “[F]orty of the US border counties have per capita income lower than the state averages". When ethnic and gender stratification are added to income data: "Hispanics, on an average, earn a lower income than non-Hispanic whites [...] [and] Hispanic women's earnings are $37 \%$ of non-Hispanic white men" (Lusk; Staudt; Moya, 2012, p. 26). Furthermore, "[...] the unemployment rate [in some border areas] is $250-300 \%$ higher than in the rest of the country" (Lusk; Staudt; Moya, 2012, p. 26), and in the rural US-MX borderlands gaining employment can be difficult.

In addition to the economic inequities, linguicism, racism, and xenophobia have long characterized the US-MX border regions. Increased border security after 9/11 combined with a decades-long pattern of anti-immigrant legislation that targets MX-US border communities have illuminated the power and opportunity differentials across the US and Mexican sides of the border (Torres, 2012). In Arizona, the border regions have become militarized to "[...] stem the tide of illegal immigrants and drugs” (Lusk; Staudt; Moya, 2012, p. 19). In 2012 alone, the corridor leading from the US-MX border to Tucson had the highest number of border agents $(4,239)$ and arrests $(120,000)$ along the US-MX border. This approach has increased law enforcement jobs and detention centers for immigrants, but it has not resulted in sustainable investments in the border's economic or educational systems.

Several pieces of Arizona State legislation explicitly target those of Mexican-descent, especially those who are presumed to be undocumented. Proposition 200, passed in 2004, prohibits undocumented individuals from state and local benefits, and requires verification of immigrant status for those seeking benefits (Campbell, 2011). Just two years later, the Arizona Constitution was amended to prohibit bail for persons charged with specific felonies if prosecutors believe that defendants are undocumented (Santos; Menjivar; Godfrey, 2013). Again in 2006, Proposition 102, which deprives undocumented immigrants the right to seek punitive damages in Arizona's civil courts, was approved (Campbell, 2011). During that same year, Proposition 300, which prohibits undocumented persons enrolled in Arizona's community colleges and universities from receiving in-state tuition rates, financial aid, or attending adult education classes, became law.

Most recently, an Arizona state bill, often referred to as show me your papers, allows law enforcement officials of the state, county, city, 
town, or other political region to determine the immigration status of an individual during a routine stop, detention, or arrest (Campbell, 2011). This legislation has been perceived as anti-Mexican. Nill (2011, p. 52) reports that "[...] seventy-three percent of Latinos think that police crack-downs on undocumented immigrants unfairly target them" and such legislation "[...] has had the effect of rendering all brown-skinned Latinos suspects” (Nill, 2011, p. 54) in Arizona.

\section{The Academic Achievement Gap}

Latinx youth in the K-16 educational pipeline are described as “[...] the largest and fastest growing group in the K12 education sector [...] nationally in 2011 there were over 12 million Latina/o students in K12, [representing] 24\% of the overall student population" (Acevedo-Gil; Santos; Solórzano, 2014, p. 1-2). These Latinx youth who are designated as English language learners in American schools, and whom we refer to as emergent bilinguals, continue to trail behind their White and Asian peers in high school graduation rates, attendance and graduation from both two-year and four-year schools, and in transfer from two-year to four-year schools (Gonzalez; Ballysingh, 2012).

Importantly, research (Koyama; Menken, 2013; Menken, 2008) has demonstrated how emergent bilinguals have been blamed as the cause of school and district failures to meet annual English language arts (ELA) and math objectives set by No Child Left Behind (NCLB), the federal education policy between 2010 and 2015. Linguistic diversity is being framed as a liability in schools within this context. NCLB mandated that all students take - and pass - high-stakes state examinations in ELA and math, but emergent bilinguals typically underperform on tests when compared to English monolinguals. Schools with too many emergent bilinguals are often seen as at-risk, and have been labeled in need of improvement, and persistently low performing across districts. Because NCLB's accountability measures required that test scores be disaggregated and reported by demographic subgroups, emergent bilinguals became circumscribed by symbolic linguistic borders.

Although many researchers (Gándara; Baca, 2008; Menken, 2008), have questioned the validity and reliability of assessments used to evaluate emergent bilinguals under NCLB, Latinx students became identified by their lower test scores. As a subgroup they often did not meet the expected cut scores, and thus their schools did not meet their adequate yearly progress objects. While all children have been affected by the policy's standardized high-stakes, the impact on emergent bilinguals, most of whom are Latinxs, has been compounded by the political discourses surrounding migration and the contestations surrounding legislation on the US side of the Mexican-US border, further perpetuating educational borders for these students (Crul; Holdaway, 2009; Gándara; Rumberger, 2009). 
Building Bridges and Borders with Deficit Thinking

\section{The College Going Lacunae}

There is a growing body of literature addressing the transfer experience of Latinx students from high school to colleges and universities (Gándara, 2010; Irizarry, 2012) Strands of inquiry have reported an overall low bachelor's degree attainment after six years of college (Ornelas; Solórzano, 2010; Núñez; Elizondo, 2013). Among these studies, researchers have uncovered a variety of issues affecting Latinx students' transition from high school to college including: attitudes about coursework, motivation to study, satisfaction with classes, involvement in social and extracurricular activities, interpersonal relationships, satisfaction with the social environment, personal and emotional health, familismo (important immediate and extended family ties), acculturation, and a sense of belonging and fitting into the college environment (Yun; Moreno, 2006).

Gándara (2010, p. 24) aptly summarizes the unwavering patterns in what is often referred to as a crisis in Latinx education as follows:

Latinos are the least educated of all major ethnic groups [...] although a large gap exists between the college completion rates of whites and blacks, both groups show steady growth. However, the growth in college degrees for Latinos is almost flat. The failure over more than three decades to make any progress in moving more Latino students successfully through college suggests that what we have been doing to close achievement gaps is not working.

That Latinxs continue to be underrepresented in postsecondary education has been attributed to a variety of borders delimited by language, finances, academic preparation, and immigration status (Irizarry, 2012; Ornelas; Solórzano, 2010). Several studies (Núñez; Elizondo, 2013; Robles-Lopez, 2017) have centered on Latinx community college students and their transfer rate, estimated to be $10 \%$, to four-year institutions. Due to the open access and admissions structure, the offering of developmental (remedial) coursework for underprepared students, and the affordability and proximity for many traditional high school students, community colleges attract a significant percentage of Latinx students (Martinez; Fernandez, 2004; Kurlaender, 2006). As noted by Rendón (1993, p. 12), the transition from high school to the community college can be a daunting process for many Latinx students:

\footnotetext{
The community college is a critical institution for students of color. It is not only a place to learn; it is a place that matters. It matters because the community college represents hope, opportunity, and for many minority and majority students, one last chance to succeed.
}

Further, Gándara (2010) notes that many Latinx students emerge from the K-12 system having attended schools that were racially segregated and financially under resourced. 


\section{Bridges}

A handful of scholars (See, for example, Llamas; López; Quirk, 2014) have examined high school to college bridge programs, in general, and specifically ones in which student participants are mostly Latinx. Other studies explore college-going culture and special programs designed to specifically serve at-risk students in college (Cabrera; DeilAmen; Prabhu, Terenzini; Franklin Junior, 2006). Much of this research focuses on the ways in which bridge programs aim to create, and make the most of, connections and contexts rich in social capital in their efforts to increase student success. We are particularly interested in the studies on Advancement via Individual Determination (AVID), the program at the center of this study. AVID is a high school to college bridge program federally funded via the U.S. Department of Education that is designed to help underachieving students with high academic potential prepare for entrance to colleges and universities. AVID seeks to recruits students at-risk, defined as those who are primarily from low income and ethnic or linguistic minority backgrounds, and to target programming around college preparation. Students recruited to AVID tend to be first generation college students and therefore are seen as typically lacking social and cultural capital in approaching career and college decision-making. In the Arizona, AVID students are often Latinx.

In their qualitative and quantitative analysis of two AVID programs in central California, Llamas, López and Quirk (2014, p. 196) found evidence suggesting AVID “[...] improved school support and engagement, as well as in the development of individual resilience factors, such as self-awareness, problem-solving ability, and self-esteem". Further, evaluating the effectiveness of the AVID program from the students' perspectives and measuring their academic success in comparison to non-AVID students, they reported: AVID students have increased school support, social connections/networking, higher levels of engagement, and both higher aspirations for and participation in advancedplacement high school courses and/or college coursework.

In another study that examined the efficacy of AVID Bridge programs, Watt, Johnston, Huerta, Mendiola, and Alkan (2008) conducted a multiple case study. Utilizing a mixed methods approach, they examined four southern Texas and four southern California high schools. Three of the four Texas high schools reported a student Latino/Hispanic population rate of $94 \%$ or higher, while the average of the four California schools was $46 \%$ student Latino/Hispanic. The researchers examined why some schools are more successful at retaining AVID students through their senior year to graduation. Participants, who were not disaggregated by gender, included 180 senior students, 138 teachers, and 12 administrators. Findings demonstrate that students who left reported not feeling motivated to be academically successful beyond high school, while those who stayed noted the importance of the social connections/networking and family atmosphere that AVID provided.

The findings of the studies on AVID mirror some of those found in broader studies of high school to college support programs. In their 
review of college-based programs that increase achievement for Latinx college students under consideration for Examples of Excelencia, they identified what they refer to as traction enablers, program components that facilitate capacity. These included collecting and using data to drive practices, but they also included tailoring programs to meet the needs of the particular Latinx students. Conversely, the slippage points, or limitations of programs included a lack of connection to, and tracking of, students in the program. Similarly, Martinez and Fernandez (2004, p. 58) identify three non-AVID community college bridge programs that succeed by "[...] adapting multicultural ideas that integrate family, community, and K-12 school systems". The success of the programs, they argue, center on developing and sustaining networks of relationships.

Similarly, in her research on dropout prevention and college going programs for Latinx high school students on the West Coast region of the United States, Gándara (2010, p. 28) found that the following practices were helpful to student's academic success:

\begin{abstract}
Providing at least one key person responsible for connecting and knowing the student, structuring a supportive peer group, providing access to strong curriculum that leads to college preparation, attending to students' cultural backgrounds, and showing students how they can finance their education, which included providing scholarships when possible.
\end{abstract}

As demonstrated by Gándara's research, Latinx students often require a tiered approach of support services to foster academic success; these practices may also be applicable in the community college setting.

In this paper, we move our focus from measures of academic success related to bridge programs to document the experiences and perceptions of Latinx youth within one program. We follow Fernandez (2002, p. 47) who calls for the greater utilization of Latinx student narratives in research. She writes:

\begin{abstract}
Educational research on Latinas/Latinos has often focused on low academic achievement. Among issues affecting Latina/Latino students are segregated schools, inequities in school finance, lack of bilingual education programs, and tracking into vocational and special education classes, to name just a few [...] [R]esearch and policy reports may document educational conditions that affect Latina/Latino students, they seldom incorporate students' own perspectives on their education. Moreover they do not acknowledge how these students cope with or respond to these educational conditions.
\end{abstract}

Latinx student voices inform our understanding, and in the following excerpts from the study, we juxtapose them with the narratives of a counselor, a teacher, and a principal associated with the bridge program to reveal the construction of symbolic and social borders, as well 
as the enactment of common deficit thinking that include discourses of colorblindness and risk.

\section{At-Risk Discourses Embedded in Borders and Bridges}

The term at-risk is often used, in education reform and policy, to describe students or groups of students who are deemed to have a higher than average probability of failing academically or dropping out of school. In US schools the term is used ubiquitously and ambiguously, often without precise reference to what situations, characteristics, behaviors, or conditions place the students at-risk. As noted by Bialostok (2015), the term is used as a catchall to indicate a wide range and disparate set of conditions and circumstances that can lead to lowered academic engagement and achievement. He points out:

Schools [...] deploy the 'at-risk' label to manage unruly student populations. Educational experts such as psychologists, counselors, social workers, special educators, and speech specialists evaluate and assess students at all levels to determine if possible risks of learning deficits, developmental delays, autism, hyperactivity, depression and learning disabilities. Some refer to anticipated negative trajectories and outcomes [...] (Bialostok, 2015, p. 565).

In fact, at-risk labels are used to reference and categorize abroad spectrum of factors that impede students' academic engagement and completion. The term can point to conditions such as incarceration, homelessness, illness, or poverty as well as learning disabilities, disciplinary issues, or persistently low test scores.

In this paper, we are particularly concerned about the ascription of blame in at-risk labeling and categorization. At-risk categories serve to construct and maintain cultural borders, as well as create a locus of blame. Risk narratives, which emerge from deficit thinking, function, in part, to construct and maintain otherness. For students who do not speak English as their first language, including some Latinx students, the primary language spoken in the home can be the cause for their at-risk status. These students become "[...] a representative of a family and symbolizes the severity of the difficulties within the family unit" (Palmo; Palmo, 1989, p. 45). They are positioned, because of their culture, their family, and their home language as having deficits. For Latinx students in Arizona this is compounded by the racists and classist discourses circulated and enacted across multiple settings, including schools.

At-risk thinking serves to provide both a map and an explanation for events that will or have occurred. Factors associated with risk have been used both to explain variable Latinx academic achievement and to justify policies that culturally and linguistically segregate emergent bilinguals and other immigrants (Koyama, 2015). Latinx are often caught in these discourses and placed in programs and classes aimed at at-risk youth, such as those offered by AVID. We became interested in 
studying AVID to better understand how the educators and students in this bridge program experienced and enacted notions of risk and deficit while simultaneously aiming to overcome them.

\section{Examining the Experiences of Latinx Students in an AVID Program Approach}

This case study utilizes a sociocultural lens to examine the experiences of Latinx students in an AVID program in Southern Arizona (Desjardin, 2016). As defined by Yin (2009, p. 18), a case study is “[...] an empirical inquiry that investigates a contemporary phenomenon within its real-life context especially when the boundaries between the context and the phenomenon are not clearly evident". Here, the second author employed this approach to study the AVID program as a complex phenomenon influenced by broader at-risk discourses in a multiply bordered context. The aim was to explore and document the participants' actions, interactions, and interpretations of the program. In our analysis, we pay particular attention to the localization of broad borderscape thinking and border discourses in the program to interrogate the practices and policies of the AVID program. Informed by interview, observation, and document data, this case study centers on how Latinx students experience the program, and how educators associated with the program interpret and understand the program.

\section{Site}

Metro High School is located in southeastern Arizona and is located in the heart of a metropolitan city. The school demographics are: $67 \%$ Hispanic, $17 \%$ White, $6 \%$ Black, $4 \%$ Asian, 3\% American Indian, and $3 \%$ who identify as bicultural; 430 seniors, $56 \%$ male and $44 \%$ female, with a total enrollment of 1,168 students. Ninety percent of the students are free-lunch eligible (NCES, 2013). Additionally, the school boasts a $74 \%$ graduation rate and during the time of the study had been labeled by the Arizona Department of Education as a high-achieving school. Metro High School is one of four high schools (three traditional and one alternative) in the Southwestern School District system.

\section{Participants}

The participants in the study included eight Latinx students and three educators associated with the AVID program ${ }^{3}$. The three educators self-identified as a white female teacher, an African American counselor, and a Native American principal, respectively. The teacher had worked in the Southwestern School District and at Metro High School for 28 years as a science teacher and was a first-time instructor for the senior cohort of the AVID program during the study. The counselor had worked within the District for 10 years and at Metro High School for one year. The principal had held his position at Metro for four years and had 
previously worked for five years in the District prior to becoming the principal.

\section{Data collection}

Semi-structured interviews, averaging half an hour were conducted with the students in a private patio at their school. The questions aimed to illuminate 1.) the strategies the students employed to achieve their academic goals, in general, and 2.) the strategies they used to navigate academic challenges. The interviews also probed the students' understandings of the broad sociocultural frames in which the school and AVID was situated. They were purposefully prompted to consider if the geographic location, near the U.S./Mexico border, and the politics associated with region influenced their post-secondary aspirations. Semistructured interviews, which lasted approximately one hour, were conducted with the educators in their offices. The questions asked of the educators paralleled those asked of the students. They centered on exploring how the leaders saw and interpreted the Latinx students' strategies in the AVID program, and also how they understood the impact of the region and politics on the students' experiences. All interviews were audio-recorded and transcribed fully.

The second author also conducted participant observations in both the junior and senior AVID cohort courses, as well as in the areas adjacent to the classes and the educators' offices. Twenty hours of observations, in which fieldnotes were made on school culture, studenteducator interactions, and setting. Photos were also taken of posters, bulletin boards, and other materials that were displayed by, for, or near the AVID classrooms, and throughout the common areas of Metro High School. Of particular interest were those posters, notices, and bulletin boards aimed at college going. These varied, but included pennants of various colleges, as well as a wall of fame, on which photos and bios of college-bound students were posted. These materials have been treated as data.

\section{Analysis}

Analysis of data was ongoing. Following Saldaña (2013), the data were coded in two cycles. As "[...] coding is not a precise science it is primarily an interpretative act [...] [it] can sometimes summarize, distill and condense data, not simply reduce them" (Saldaña, 2013, p. 4), the codes for this study included not only words, but also short phrases "[...] that symbolically assigns a summative, salient, essence-capturing and/ or evocative attribute for a portion of language-based or visual data" (Saldaña, 2013, p. 3). During the first cycle of coding, the second author applied both deductive and inductive codes. During the second cycle of coding, the two authors discussed the coded portions of the data, which were further coded, but which were also then compared across the data. Maxwell (2012) describes this practice as one of both comparing and 
affirming that what the participants perceived and described as occurring was in fact happening.

\section{Bridging (?) the Disparities across the AZ-MX Border}

In the study, those working in the AVID program were aware of the economic disparities and challenges faced by many Latinx families, especially those who were first generation US residents. The teacher explained:

One thing that is interesting is just how school is a middle class way of approaching the world, and there's all kinds of hidden things in terms of how to be successful in school that kids who come from a high poverty background [...] It might seem really obvious to people who come from a middle class background, but it really isn't, and teaching kids about that hidden structure, that middle class structure of things (Teacher Interview, 2015).

The counselor added:

A lot of times, there's concerns that there's not a lot of parental involvement but I think it could be the fact that a lot of our parents are in survival mode. A lot of times they're working. They're just trying to day to day make it. It may not be because not caring but because they have so much going on in their lives and its survival mode (Counselor Interview, 2015).

Despite noting that many of the Latinx families are economically challenged, the counselor seemed unaware, or at least insensitive, in also seeing how those challenges affect the students. She commented:

I think sometimes the students right now are struggling with [...] realizing what they need to do and how to go to that next step. Preparing and planning is important. It seems to them they're living today and not thinking about tomorrow. What they need to do to get there. Some of them what happens is that it happens as freshmen. They don't do well and then they're trying to play catch up. I see a lot of that. It's 'now I need to plan or need to do it' when it should've been decided early on.

Positioning the Latinx students as not knowing reflects deficit thinking that centers the absence of knowledge in individuals, families, or even cultures, rather than within the educational system that persistently under serves and under resources Latinxs. It also does not counter this assumption with the strengths brought to US schooling by these particular students, their families, and their cultures. These Latinx youth are seen as at risk academically partially because of their familial backgrounds, their socioeconomic status, and their parents' need to work multiple jobs. In fact, the notion that Latinx youth are academically behind because they don't plan serves as a way to construct and maintain cultural and ethnic borders. The counselor and teacher's comments place the blame solely on the Latinx youth and their families. 


\section{Bridging (?) the Achievement Gap}

To attend to the academic achievement gap faced by many Latinxs, AVID purports using a rigorous academic elective course with a sequential curriculum for grades seven through twelfth that focuses on writing, inquiry, and collaboration as methodologies to accelerate student progress (Llamas; López; Quirk, 2014). However, in the study, it was revealed that the AVID program at this particular school used the understanding poverty framework of Ruby Payne's (2005). In response to being asked what type of research or theories were used in the program, the AVID teacher answered:

What we're using here at school more recently has been some of Ruby Payne's work that's connected to working with kids who come from high poverty backgrounds, but that is not specifically one particular ethnicity. It's more a socioeconomic thing (Interview, 2015).

In her work Payne argues that when middle class teachers better understand the cultural gap between their poor students and themselves, they can help students achieve academically. She rarely discusses race or ethnicity in the workshops she has built around her framework.

In fact, work of Payne (2005), who proclaims to be the leading US expert of the mindsets of social class, has been widely criticized for reifying the culture of poverty, introduced by Oscar Lewis (see for examples, Bomer; Dworin; Semingson, 2008; Valencia, 2010) ${ }^{4}$. Further, Payne's curricula and professional development materials routinely use ethnic stereotypes while adopting colorblindness or denying the existence of negative racial or racialized cultural and ethnic experiences (Alvarez McHatton; Shaunessy; Hughes; Brice; Ratfliff, 2007). Nonetheless, despite what is recognized as an extreme deficit perspective replete with cultural and ethnic stereotypes, Payne's curricula and training packets are used by thousands of US public school teachers (Valencia, 2010), including the one in this study.

Payne's materials appeared to have an impact on the Latinx students, who selectively identified the salience of their own, often racialized, culture and ethnicity on their experiences in the AVID program. When asked to describe their experiences as Latinx students and to discuss any role that their culture played, Cristina, a female student answered:

I don't feel different from other students - at least it can be easier to take college classes, maybe Spanish, but other than that it's not really [...] I just see myself as a regular student [...]. Being Latina helps [...] so that's one way that my Counselor helps me because they have a lot of specific Latina scholarships that they help me with [...] but as a culture, I feel they try to not have anything directly towards the culture so [...] (Interview, 2015).

When asked if the student was concerned that there wasn't anything directly targeted at culture, she responded: 
Yeah I don't really mind it, it doesn't really impact me as long as, I'm not being discriminated or it's holding me back from an opportunity (Interview, 2015).

We can see from Cristina's responses that she has an awareness that overt discrimination based on her ethnicity and culture would be wrong, but she also notes the opportunities - in this case scholarships - targeted to Latinx students. Another female student, Juanita, also stated that her culture did not necessarily play a role in her experiences in AVID. She stated:

My cultural role, I don't think it's that really big in my standards. Everyone else thinks it's big [...] My experience as a Latina in this school is not really that different. [...] You feel somehow you can socialize with anyone. It's just who you feel a part of. It doesn't really matter what race or gender, you are (Interview, 2015).

The students' responses likely reflect the colorblind ideology, which was evident across the school, and especially in the AVID program, where there were no postings or materials about Latinx culture or Latinx role models among the many posters and bulletin boards. According to Alvarez McHatton et al. (2007), responses given by students, like those in our study, are common as students struggle to connect their cultural/ethnic/racial identity with an academic identity. Although such colorblindness seems at odds with other deficit thinking based on the ways in which particular groups, often based on race, ethnicity, language, culture, or socioeconomic groupings, are at risk, it is actually just the other side of the same coin. Colorblindness ties negative educational trajectories and outcomes to individuals and denies the experiences of traditionally marginalized populations, often rejects the role of culture, and invalidates their perspectives as different from the middle-class white mainstream. Both of the perspectives place the risk of educational failure at the level of the individual.

The color-blind ideologies that emerged from participant narratives in both the students and educators appeared to the second author to be expressed as tacit cultural knowledge. Spradley $(1980$, p. 6) notes that cultural knowledge as "[...] the acquired knowledge people use to interpret experience and generate behavior". He states that we experience cultural knowledge at two levels of consciousness, explicit (what we are aware of and can communicate) and tacit (subliminal, or outside our awareness). Although participants were able to describe this phenomenon, naming it as an oppressive or deficit force at play within the school or program was not at a level of critical consciousness of the participants.

Homogenizing discourses also mutually construct and reflect colorblind perspective and were reflected on bulletin boards and posted notices promoting college going which did not mention ethnicity, gender, or race. One male participant, Rene explained:

My experience as a Latino student at the school is a little bit different, but, also I feel like there there's many more Latinos around me being that 
we're in Southern Arizona. A lot of people think differently about Latinos, they usually think it's always from Mexico or you were born in Mexico, it's the same thing. Everybody assumes it's the same situation for everybody but it's really not like that. I was born here, I was raised here, so it was different for me growing up here, opposed to people I know that grew up in Mexico. We have our differences but yet we have our similarities as well.

Chavez-Dueñas, Adames and Organista (2013, p. 14) point to the danger of using "Latinos/as a pan-ethnic label as it may lead to the perception of a homogenous group where everyone is of mixed racial makeup, thus promoting a color-bind racial ideology within the Latino population". The ambivalence that Rene feels with distinguishing himself as being born here, while still representing his lineage, is evidenced. Valenzuela (1999) discusses how subtractive schooling practices that devalue cultural wealth and promote assimilation add to this state of confusion for Latinx youth who struggle with living as both an insider and an outsider simultaneously.

\section{Bridging (?) the College going Border}

Discussing the role that Latinx students' families need to play, the principal points to the seeming lack of understanding and cultural capital held by the parents. According to the principal, the lack of familiarity with negotiating the transition from high school to college, is not rooted in Latinx culture and familial resources. He posited:

[...] [I]t's not even Latino Latina, but it ends up being a large chunk of the population we deal with here where they don't understand what the steps are getting into college. You've seen this. 'What do you do? What is a FAFSA? When should I apply?' All those things, they just don't understand them. It's not because they're Latino Latina. None of the families have ever gone through that (Interview, 2015).

However, as he continued by further noting that not only do the students' families not have experience in navigating college applications and funding, they do not understand of timeliness and prioritizing. He stated:

The family understanding of what has to happen for students to be ready for those next steps [...] sometimes they don't understand the importance of being on time every day, having a space at home to do homework, and that's not the priority, family, cultural factors, take over [...] it's not the fault of anyone [...] they don't understand the steps to getting into college [...] those are cultural things, where family may trump those steps (Interview, 2015).

In this particular characterization of Latinx families, the principal is offering a deficit perspective, in which the students' parents, guardians, and other family members make the youth at-risk of failing academically. He qualifies that it isn't anyone's fault, but then essentially blames the family and the culture. They are, the loci of risk and danger. Here, we see how risk is seen as a negative that can be mediated with the right kinds of school supports, rather than a disaster that can- 
not be addressed. Risks associated with Latinx students can be, in his understanding, managed by educators at schools.

The counselor is more explicit about the risk students' families pose to their children's college going. She recounted:

I think they [parents] have a lot of influence. We do have some students, one in particular I'm thinking of, he was going to go to the [local public university] but then his mom talked to him about he needed to go to [the local public community college]. This same one I was talking about, I felt academically he's strong. I think he could make it but mom is not feeling that way. She influenced him to go to the [local public community college]. I have seen they have quite an influence, most of the ones that are pretty involved (Interview, 2015).

In these responses, especially the counselor's, there is a lack of consideration and acknowledgement about the complex interaction of multiple factors families put into college-going decisions. She does not, for instance, discuss the difference in cost between the university and community college, or the other responsibilities that a student might need to consider, including those to his family or work, which also affect his choice in institutions. And, she does not mention his academic and career interests, which should be an important consideration when choosing a college. Perhaps, the counselor is well meaning, but seemingly unaware of that she is blaming the mother for what might have been a very reasoned decision.

\section{Future Directions in Researching AVID and other Bridge Programs}

As described by Anzaldúa (1987, p. 25), residing near the U.S./ Mexico border is equivalent to negotiating a borderland wherein, "[...] the Third World grates against the first, and bleeds. And before a scab forms it hemorrhages again, the lifeblood of two worlds merging to form a third country-a border culture. Borders are set up to define the places that are safe and unsafe, to distinguish us from them". When it comes to educational contexts, many Latinx youth are caught between these worlds - the U.S. and Mexico - and are consequently treated as other despite the fact that they are the numerical majority in the Arizona K-12 school system (Milem; Salazar; Bryan, 2016). Hence, Latinx youths' lived experiences are marked as representing the exception when in fact, their numerical majority should give them the power to define the norm.

In schools, symbolic borders - those borders that serve as conceptual distinctions constructed "[...] by social actors to categorize objects, people, practices, and even time and space” (Lamont; Molnár, 2002, p. 168) - can become social borders for Latinx youth. Through educational policy, pedagogy, and curricula, they "[...] can take on a constraining character and pattern social interaction in important ways" (Lamont; Molnár, 2002, p. 168-69). These borders are deeply embedded with atrisk narratives that allow well-intentioned programs, like the AVID 
bridge program examined in this paper, to default to a deficit and colorblind perspectives - the pernicious ideas "[...] that minority students labor under intellectual handicaps because of their family structure, linguistic background, and culture" (Valencia, 2010, p. 9) - with regard to Latinx students and their families ${ }^{5}$.

Research on AVID has been theoretically thin and have focused predominantly on the benefits of AVID for students without problematizing the underlying deficit assumptions guiding the programs. Furthermore, even when studies aim to provide comparative data across multiple bridge programs, there is insufficient and inconsistent records with which to work. More salient to our concerns, is that there exists insufficient research that interrogates programs, including bridge programs like AVID, which claim to provide passage across multiple borders.

We must challenge even those programs, like AVID, with whose aims we may partially agree. At a minimum, we must turn at-risk models and discourses upside down. As Valencia (2010) demonstrates, educational leaders must counteract the current deficit frames inherent in our institution hierarchies with effective practices such as: soliciting parental involvement by establishing door to door visits to pass out information about school activities, and community engagement utilizing an oral histories approach to highlight community member achievement for integration and display at school. Further, educational leaders can adopt culturally sensitive teaching models as mentors for other teachers, coach teachers in developing cultural responsiveness, and create teams of equity advocates as embedded practices into the school culture. Moreover, as Valencia suggests such social justice leadership practices must place student academic achievement, not as solitary goals, but as byproducts of these efforts.

We argue for a closer examination into the deficit-thinking rooted in programs that serve Latinx students, the fastest growing ethnic group in the US's total student population. While it would be unconscionable to consider closing borders in opportunities and access in education for Latinxs, it is also irresponsible to focus research attention on the outcomes of programs, like the one discussed in this piece, without critically examining, and disrupting, the program's philosophies and practices. We suggest a closer examination of school settings and programs that serve as borderscapes. It is the responsibility of those of us who study education to draw continued attention to the ways in which discourses of inequity and deficit are perpetuated.

Received on December 10, 2017 Approved on September 4, 2018

\section{Notes}

1 We use the term Latinx (pronounced La-TEEN-ex) as a gender-inclusive term, replacing Latino/a. The term, which is used mostly in the US by activists and 
Building Bridges and Borders with Deficit Thinking

academics, also encompasses genderqueer and gender-nonconforming people of Latin American heritage. We use Latino/a when directly citing other scholarship.

2 García (2011, p. 41) has argued for "[...] the use of the term emergent bilingual in referring to these children as a way to remind all of us that the effective teaching of English will make them bilingual, not merely teach them English". Meanwhile, the U.S. government still uses the term limited English proficient, which went out of usage in many school systems for its deficit orientation. In this manuscript, we use emergent bilingual in lieu of English language learner or limited English proficient unless discussing official designation or quoting participants.

3 All eleven students in AVID were invited to participate in the study.

4 See also: Ferlazzo (2012).

5 For a full discussion of deficit thinking in education, see Valencia (1997; 2010).

\section{References}

ACEVEDO-GIL, Nancy; SANTOS, Ryan; SOLÓRZANO, Daniel. Examining a Rupture in the Latina/o College Pipeline: developmental education in California community colleges. Perspectivas: Issues in Higher Education Policy and Practice, San Antonio, n. 3, p. 1-19, 2014. Available at: <https://files.eric.ed.gov/ fulltext/ED571020.pdf>. Accessed on: Sept. 9, 2018.

ALVAREZ MCHATTON, Patricia; SHAUNESSY, Elizabeth; HUGHES, Claire; BRICE, Alejandro; RATLIFF, Mary Ann. You Gotta Represent! Ethnic Identity Development among Hispanic Adolescents. Multicultural Perspectives, Washington D.C., v. 9, n. 3, p. 12-20, 2007.

ANZALDÚA, Gloria. Borderlands: la frontera (volume 3). San Francisco: Aunt Lute, 1987.

BIALOSTOK, Steve. Risk Theory and Education: Policy and Practice. Policy Futures in Education, Wallingford, v. 13, n. 5, p. 561-567, 2015.

BOMER, Randy; DWORIN, Joel; MAY, Laura; SEMINGSON, Peggy. Miseducating Teachers about the Poor: a critical analysis of ruby payne's claims about poverty. Teachers College Record, New York, v. 110, n. 5, p. 2497-2531, 2008.

CABRERA, Alberto F.; DEIL-AMEN, Regina; PRABHU, Radhika; TERENZINI, Patrick T.; LEE, Chul; FRANKLIN JUNIOR, Robert E. Increasing the College Preparedness of At-Risk Students. Journal of Latinos and Education, Mahwah, v. 5, n. 2, p. 79-97, 2006.

CAMPBELL Kristina M. The Road to SB 1070: How Arizona became Ground Zero for the Immigrants' Rights Movement and the Continuing Struggle for Latino Civil Rights in America. Harvard Latino Law Review, Cambridge, v. 14, n. 1, p. 1-23, 2011.

CHAVEZ-DUEÑAS, Nayeli; ADAMES, Hector Y.; ORGANISTA, Kurt C. SkinColor Prejudice and Within-Group Racial Discrimination: historical and current impact on Latino/a populations. Hispanic Journal of Behavioral Sciences, Thousand Oaks, v. 36, n. 1, p. 3-26, 2013.

CRUL, Maurice; HOLDAWAY, Jennifer. Children of Immigrants in Schools in New York and Amsterdam: the factors shaping attainment. The Teachers College Record, New York, v. 111, n. 6, p. 1476-1507, 2009. 
DESJARDIN, Suzanne. Living Within and Outside the Margins and Borders:The Impact of School Leadership on Successful Bridge Programs and Latino/a Transitions to Community College and Beyond. 2016. Dissertation (Ph.D. in Educational Leadership and Policy Planning) - Educational Policy Studies and Practice, College of Education, University of Arizona, Tucson, 2016.

FERLAZZO, Larry. The Best Critiques of Ruby Payne. Larry Ferlazzo's Websites of the day, Sacramento, Jan 24, 2012. Available at: <http://larryferlazzo.edublogs.org/2012/01/24/the-best-critiques-of-ruby-payne/commentpage-3/>. Accessed on June 25, 2015.

FERNÁNDEZ, Lilia. Telling Stories about School: using critical race and Latino critical theories to document Latina/Latino education and resistance. Qualitative Inquiry, Thousand Oaks, v. 8, n. 1, p. 45-65, 2002.

GÁNDARA Patricia. The Latino Education Crisis. Educational Leadership, Alexandria, v. 67, n. 5, p. 24-30, 2010.

GÁNDARA, Patricia; BACA, Gabriel. NCLB and California's English Language Learners: the perfect storm. Language Policy, Dordrecht, v. 7, n. 3, p. 201-216, 2008.

GÁNDARA, Patricia; HOPKINS, Megan. Forbidden Language: English learners and restrictive language policies. New York: Teachers College Press, 2010.

GÁNDARA, Patricia; RUMBERGER, Russell. Immigration, Language, and Education: How does Language Policy Structure Opportunity? The Teachers College Record, New York, v. 111, n. 3, p. 750-782, 2009.

GARCÍA, Ofelia. Educating New York's Bilingual Children: constructing a future from the past. International Journal of Bilingual Education and Bilingualism, London, v. 14, n. 2, p. 133-153, 2011.

GONZALEZ, Jeremiah. Understanding the Role of Social Capital and School Structure on Latino Academic Success. LUX: A Journal of Transdisciplinary Writing and Research from Claremont Graduate University, Claremont, v. 2, n. 1, 2013. Available at: <http://scholarship.claremont.edu/lux/vol2/issl/16>. Accessed on: 26 April 2017.

GONZALEZ, Kenneth P.; BALLYSINGH, Tracy Arámbula. Increasing Latina/o College Completion: mistakes and opportunities. Journal of Hispanic Higher Education, Thousand Oaks, v. 11, n. 3, p. 279-290, 2012.

IRIZARRY, Jason. Los Caminos: Latino/a youth forging pathways in pursuit of higher education. Journal of Hispanic Higher Education, Thousand Oaks, v. 11, n. 3, p. 291-309, 2012.

KOYAMA, Jill. Learning English, Working Hard, and Challenging Risk Discourses. Policy Futures in Education, Wallingford, v. 13, n 15, p. 608-620, 2015.

KOYAMA, Jill; MENKEN, Kate. Emergent Bilinguals: framing students as statistical data? Bilingual Research Journal, Washington D.C., v. 36, n. 1, p. 82-99, 2013.

KURLAENDER, Michal. Choosing Community College: factors affecting Latino college choice. New Directions for Community Colleges, New York, n. 133, p. 7-16, 2006.

LAMONT, Michèle; MOLNÁR, Virág. The Study of Boundaries in the Social Sciences. Annual Review of Sociology, Palo Alto, v. 28, n. 1, p.167-195, 2002.

LLAMAS, Jasmín D.; LÓPEZ, Susana; QUIRK, Matthew. Listening to Students: examining underlying mechanisms that contribute to AVID program effective- 
Building Bridges and Borders with Deficit Thinking

ness. Journal of Education for Students Placed at Risk, Mahwah, v. 19, n. 3, p. 196-214, 2014

LUSK, Mark; STAUDT, Kathleen; MOYA, Eva M. Social Justice at the Border and in the Bordered United States: implications for policy and practice. Social Justice in the US-Mexico Border Region, Dordrecht, p. 247-269, 2012.

MARTINEZ, Magadelena; FERNÁNDEZ, Edith. Latinos at Community Colleges. New Directions for Student Services, Hoboken, n. 105, p. 51-62, 2004.

MAXWELL, Joseph A. Qualitative Research Design: An Interactive Approach. Thousand Oaks, CA: Sage Publications, 2012.

MENKEN, Kate. English Learners left Behind: Standardized Testing as Language Policy. Bristol: Multilingual Matters, 2008.

MILEM, Jeffrey F.; SALAZAR, Karina G.; BRYAN, W Patrick. Arizona Minority Student Progress Report 2016: the transformation continues. Tucson: AMEPAC, 2016. Available at: <https://highered.az.gov/sites/default/files/16\%20MSRP\%20 Report.pdf>. Accessed on: 26 April 2017.

NATIONAL Center for Education Statistics (NCES). The Condition of Education 2013. Washington D.C.: NCES, 2013. Available at: <https://nces.ed.gov/ pubs2013/2013037.pdf>. Accessed on: Sept. 9, 2018.

NILL, Andrea Christina. Latinos and SB 1070: Demonization, Dehumanization, and Disenfranchisement. Harvard Latino Law Review, Cambridge, MA, v. 4, p. 14-35, 2011.

NÚÑEZ, Anne-Marie; ELIZONDO, Diane. Closing the Latino/a Transfer Gap: creating pathways to the baccalaureate. Perspectivas: Issues in Higher Education Policy and Practice, San Antonio, n. 2, p. 1-15, 2013. Available at: <http:// files.eric.ed.gov/fulltext/ED571016.pdf>. Accessed on: 26 April 2017.

ORNELAS, Armida; SOLÓRZANO, Daniel. Transfer Conditions of Latina/o Community College Students: a single institution case study. Community College Journal of Research and Practice, London, v. 28, n. 3, p. 233-248, 2010.

PALMO, Artis J.; PALMO, Linda A. The Harmful Effects of Dysfunctional Family Dynamics. In: CAPUZZI, David; GROSS Douglas R. (Ed.). Youth at Risk: a resource for counselors, teachers, and parents. Alexandria: American Association for Counseling and Development, 1989. P. 43-70.

PAYNE, Ruby. A Framework for Understanding Poverty. Highlands: RFT Publishing, 2005.

RAJARAM, Prem Kumar; GRUNDY-WARR, Carl (Ed.). Borderscapes: hidden geographies and politics at territory's edge. Minneapolis: University of Minnesota Press, 2007.

RENDÓN, Laura I. Eyes on the Prize: students of color and the bachelor's degree. Community College Review, Thousand Oaks, v. 21, n. 2, p. 3-13, 1993.

ROBLES-LOPEZ, Irene. Latino Males in the Borderland: a case study analysis of successful transfer from the community college to the university. 2017. Dissertation (Ph.D. on Educational Leadership and Policy Planning) - Educational Policy Studies and Practice, College of Education, University of Arizona, Tucson, 2017.

SALDAÑA, Johnny. The Coding Manual for Qualitative Researchers. 2. ed. Thousand Oaks: SAGE Publications LTD, 2013.

SANTOS, Carlos; MENJIVAR, Cecilia; GODFREY, Erin. Effects of SB 1070 on Children. In: MAGAÑA, Lisa; LEE, Erik (Ed.). Latino Politics and Arizona's Immigration Law SB 1070. New York: Springer, 2013. P. 79-92. 
SPRADLEY, James. Participant Observation. Belmont: Wadsworth, 1980. TORRES, Rosalía Solórzano. Border Challenges and Ethnic Struggles for Social Justice in Arizona: Hispanic communities under siege. In: LUSK, Mark (Ed.). Social Justice in the U.S.-Mexico Border Region. Dordrecht: Springer, 2012. P. 231-246.

VALENCIA, Richard. Conceptualizing the Notion of Deficit Thinking. In: VALENCIA, Richard (Ed.). The Evolution of Deficit Thinking: educational thought and practice. London: Routledge Falmer, 1997. P. 1-12.

VALENCIA, Richard. Dismantling Contemporary Deficit Thinking: educational thought and practice. New York: Routledge, 2010.

VALENZUELA, Angela. Subtractive Schooling: US-Mexican youth and the politics of caring. Albany: State University of New York Press, 1999.

VELASCO ORTIZ, Laura; CONTRERAS, Óscar F. The Border as a Life Experience: identities, asymmetry and border crossing between Mexico and the United States. Frontera Norte, Tijuana, v. 36, n. 3, p. 37-57, 2014.

WATT, Karen M.; JOHNSTON, Dennis; HUERTA, Jeffery; MENDIOLA, Irma Doris; ALKAN, Ersan. Retention of First-Generation College-Going Seniors in the College Preparatory Program AVID. American Secondary Education, Ashland, v. 37, n. 1, p. 17-40, 2008.

WRIGHT, Wayne. The Political Spectacle of Arizona's Proposition 203. Educational Policy, Thousand Oaks, v. 19, n. 5, p. 662-700, 2005.

YIN, Robert. Case Study Research: design and methods (volume 5 of Applied Social Research Methods). Thousand Oaks: Sage, 2009.

YUN, John T.; MORENO, José F. College Access, K-12 Concentrated Disadvantage, and the Next 25 Years of Education Research. Educational Researcher, Thousand Oaks, v. 35, n. 1, p. 12-19, 2006.

Jill Koyama is Associate Professor - Educational Policy Studies and Practice - College of Education.

ORCID: http://orcid.org/0000-0003-0990-4930

E-mail: jkoyama@email.arizona.edu

Suzanne Desjardin is Dean of Social Sciences and Student Affairs.

ORCID: http://orcid.org/0000-0003-3687-4634

E-mail: sdesjardin@pima.edu

This is an open-access article distributed under the terms of the Creative Commons Attribution License 4.0 International. Available at: <http://creativecommons.org/licenses/by/4.0>. 